\title{
The Evolution of Polish National Symbols on the Example of the Flag and Anthem ${ }^{2}$
}

\begin{abstract}
The theme of this article is the evolution of the Polish flag and the anthem. These symbols were accompanied by Polish people in the most important moments of their lives. They give immigrants a sense of constant ties with their homeland. Knowledge of the history of these national symbols is important to understand the importance and the need for such things as the national flag and the national anthem
\end{abstract}

\section{Keywords:}

flag, anthem, Poland, national symbol

Each state uses at least one flag as its distinguishing mark. Frequently, two flags: national and official, are used simultaneously. The national flag is used commonly, whilst the official flag with a coat of arms in the middle of it is used only by state offices indicated in special regulations (Znamierowski, 2003).

Problems connected with the national flag are closely associated with the issue of the coat of arms. The colours presented on the flag correspond with the colouring of the coat of arms. The Polish flag combines the white of the eagle

1 University of Rzeszow.

2 The text is a modified version of the speech at the International Scientific Conference Statehood and Symbolics in Central Europe after 1989, Budapest, 2 October 2009. 
and the red of the shield of the coat of arms. Historical Polish state banners, used between the 12th and 18th centuries, usually presented a white eagle on a red field. The dark red of the field, obtained by fabric dyeing, and referred to as crimson or carmine, was typical of the Polish coat of arms and banners for a long time (Znamierowski, 2003).

During the period of the Polish-Lithuanian Commonwealth (1569-1795), the state banner included the Polish and Lithuanian symbols (The White Eagle and The Chase) (Russocki, Kuczyński, Willaume, 1978). The coat of arms was usually situated in a red field, but banners consisting of three horizontal stripes, red-white-red, of equal width, were also used.

\section{THE POLISH NATIONAL COLOURS}

The first instances of using white and red as the national colours occurred at the end of the 18th century. In 1792, i.e., the first anniversary of the adoption of the Constitution of May 3rd, a mass demonstration took place using the national colours. At first, the national colours were represented by wearing suitably coloured clothes. Afterwards, white and red round bows, pennants and armbands were used (Znamierowski, 2003).

The First Republic of Poland ceased to exist after it had been partitioned in three stages by the neighbouring states (1772-1795). Between 1795 and 1918 the Polish people attempted to regain their independence several times. One of these attempts, the November Uprising, began on November 29th, 1830, and lasted for almost 11 months. It took place mainly on the territory of the so-called Kingdom of Poland, a Russian protectorate established in 1815 by Tsar Alexander I. The national Parliament, operating during the Uprising, adopted a resolution on the national cockade. "The House of Senators and the House of Deputies [...] having considered the need to establish unified insignia, under which Poles shall unite, has decided and established: Article 1. The National Cockade shall consist of the colours of the coat of arms of the Kingdom of Poland and the Grand Duchy of Lithuania, that is, the colours white and red” (Russocki, Kuczyński, Willaume, 1978). This was the first case in Poland when the aforementioned issues were legally regulated. It should be noted that while banners with the national colours were used at that time, the colours were placed parallel to the tree (Borucki, 2006). Widespread use of amaranth red was typical of this period (Rosner, 2003).

The colours red and white became typical Polish symbols in the 19th century. These colours were used not only in Poland but also abroad, not only by Polish 
people but also by foreigners who wanted to express their fondness for Poland. Polish symbols and colours accompanied Poles who fought during the Spring of Nations in Hungary, Austria, Germany or France, or during the Russo-Turkish War in 1850s. Poles once again tried to oppose the occupants by means of organizing another armed action against the Russian Empire, the January Uprising, in 1863. Patriotic attitudes were expressed by exposing Polish national symbols, which were forbidden by the Russian authorities in 1831-1832 (Rosner, 2003). Interestingly, many flags and banners of that period were red on the top stripe and white on the bottom $^{3}$.

The form of white-red flag, which has been used until the present day, first appeared in 1916, on the 125th anniversary of the adoption of the Constitution of May 3rd. The organizers of the anniversary reminded Poles of the importance of the red and white colours. They also advised participants about the correct alignment of the colours, that is with the white stripe above the red one (Rosner, 2003). The pattern of the flag referred to medieval heraldic rules, many of which are still binding. Banners, flags and pennants were provided with colours typical of the coat of arms (Russocki, Kuczyński, Willaume, 1978). The colour of the emblem was considered the main colour and placed in an honourable location, which in the case of flags was the top stripe. The colour of the shield, being less honourable, was placed below the colour of the emblem (Górecki, 2008).

\section{THE POLISH FLAG IN THE SECOND REPUBLIC OF POLAND}

The colours of the Republic of Poland were regulated in 1919. The Emblem and Colours of the Republic of Poland Act of 1st August 1919 stipulated that "Until (the) borders are settled, and until the constitution defines the state emblems, state colours and titles of the state offices and institutions, offices of the state shall use emblems and colours consistent with the following patterns: [...] 3. [...] the national colours of Poland are white and red, in two horizontal, parallel stripes of

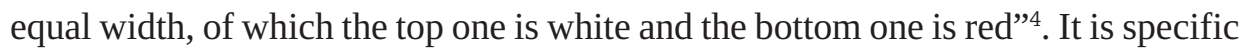
for the Act that it uses the term 'national colours' and recognizes it as a national

3 As an example, the banner of the Polish Legions in Hungary (1848) or the banner of the January Uprising can be mentioned.

4 Ustawa z 1 sierpnia 1919 r. o godłach i barwach Rzeczypospolitej Polskiej [The Act of 1 August 1919 on the Emblem and the Colours of the Republic of Poland], Dz.U. [JoL] 1919 No. 69, item 416 (Journal of Laws of the Republic of Poland, abbreviated Dz.U., is the official journal for promulgation of laws in Poland). 
symbol instead of appropriating the term for the state only. However, at the same time, the Act forbade private persons to use the flag without the permission of the Minister of Internal Affairs. The Poles were thereby deprived of the possibility to use their national symbols freely. The pattern of the flag was attached to the Act.

The Act also described the patterns of special flags to be used by state institutions, military flags, maritime ensigns, etc. One of the special flags, "flag for use by Polish diplomats and consuls abroad”, should be especially distinguished. It was a special variant of the basic flag pattern with the coat of arms set in the white stripe.

National symbols in the Second Republic of Poland were held in high esteem by the Polish people. Despite this, the state symbols were not regulated in Constitution, although they were stipulated in The Emblem and the Colours of the Republic of Poland Act of 1919. (Sarnecki, 2007). It is worth mentioning that the flag patterns attached to the Act were in black and white. Colour images of the state symbols were published two years later in a brochure disseminated by the Ministry of Internal Affairs ${ }^{5}$. The shade of shield and flag red introduced was of a crimson hue (Znamierowski, 2003).

Similarly to other legal acts adopted at the turn of 1918 and 1919, The Emblem and the Colours of the Republic of Poland Act of 1919 was temporary and was in force until 1927. It was replaced by The Emblem, Colours, Symbols, and State Seals of the Republic of Poland Decree of December 13th, $1927^{6}$. According to Article 2 of the decree, "the state colours are white and red in two horizontal, parallel stripes of equal width and length, of which the top one is white and the bottom one is red. The red colour corresponds to a cinnabar colour". Article 5 of the decree stipulated that "the state flag is a cloth of the national colours".

The decree of 1927 did not forbid the use of the flag in any particular situations. Restrictions introduced by the decree covered only the use of the coat of arms, state seals and special flags ${ }^{7}$.

The decree of 1927 also modified the state coat of arms, which altered the pattern of the flag used by institutions abroad. The flag used the coat of arms consistent with the pattern of 1927, placed in the middle of the white stripe. It was used by the émigré authorities during the Second World War and afterwards until 1990.

5 The brochure “Godło i barwy Rzeczypospolitej Polskiej” [The Emblem and Colours of the Republic of Poland] was written by Stanisław Łoza.

6 JoL 1927 No. 115, item 980.

7 Ibidem, art. 15-16. 
For Poles living abroad and for people who questioned the legality of the proRussian authorities the abovementioned flag pattern symbolized free Poland. It is still widely used by Poles, especially those who live in Northern America. The most popular variant of the flag includes the coat of arms in a form established by the émigré authorities in 1956.

\section{FLAG OF THE PEOPLE'S REPUBLIC OF POLAND}

The first legal act adopted in Poland after World War II which regulated national symbols was The Constitution of the People's Republic of Poland of July 22nd, $1952^{8}$. It was also the first Polish constitution which has ever regulated the abovementioned issue. Article 89 (2) of the Constitution, Chapter IX - "The Emblem, Colours and Capital of the People's Republic of Poland”, stipulated that "The colours of the People's Republic of Poland shall be white and red. Details concerning the colours shall be specified by other legal acts" (Sarnecki, 2007).

The legal act specifying the constitutional regulations was the State Council's decree on the Emblem and Colours of the People's Republic of Poland and the State Seals of December 7th, $1955^{9}$. According to Article 2 of that decree, "The colours of Poland are white and red, in two horizontal, parallel stripes of equal width and length, of which the top one is white and the bottom one is red, corresponding to a cinnabar colour". Article 3(1) stipulated that the state flag is a rectangular piece of cloth in the national colours: white and red. In Article 3(2), the Constitution incorrectly determined the proportions of the flag, introducing the proportion of 3:8, which extended the flag's length in relation to the former patterns. However, the proportion was restored to 5:8, i.e. the traditionally used proportions of the national and state flags, less than one year later ${ }^{10}$. The decree of 1955 did not restrict the usage of the national flag, but in the Article 13 it introduced penal responsibility for the illegal usage of the coat of arms, the flag with the coat of arms and special flags.

Subsequent alterations of the Polish national symbols took place in 1980 when an act was passed regulating the issue of national symbols in a complex way. The

8 JoL 1952 No. 33, item 232.

9 JoL 1955 No. 47, item 314.

10 Rozporządzenie Prezesa Rady Ministrów z dnia 20 marca 1956 r. o sprostowaniu błędu w dekrecie z dnia 7 grudnia 1955 r. o godle i barwach Polskiej Rzeczypospolitej Ludowej oraz o pieczęciach państwowych, JoL 1956 No. 7, item 43. 
Regulations of the Emblem, Colours and Anthem of the People's Republic of Poland Act of January 31st, 1980 were preceded by a preamble which defined the meaning of the Polish symbols for the entire nation in a momentous way ${ }^{11}$. Article 4 of the Act almost literally repeated phrases from the decree of 1955 which referred to the colours and the state flag. Article 15 of the Act ordered that the national symbols be used with honour and respect, while the conditions of their usage were to be determined by other legal acts. Displaying the white and red flag (e.g., on the 1st of May), alongside the red flag, was recognized by the Act as a citizen's duty.

The Act of 1980 altered the graphical pattern of the flag, included in the 2nd attachment to the Act. A new hue of red was introduced which was darker than a cinnabar. The attachment provided precise, technical coordinates for the colours, white and red, instead of the former verbal prescription. "Trichromatic coordinates of the $\mathrm{x}$ and $\mathrm{y}$ colours, their component $\mathrm{Y}$ and tolerated colour $\Delta \mathrm{E}$ differences in the CIE $1976\left(\mathrm{~L}^{*} \mathrm{u}^{*} \mathrm{v}^{*}\right)$ colour space, established according to CIELUV with the Illuminant $\mathrm{C}$ and measuring geometry $\mathrm{d} / 0$ ”. A table attached to the Act indicated that the coordinates $\mathrm{x}, \mathrm{y}, \mathrm{Y}$, and $\Delta \mathrm{E}$ for the white colour are adequately: 0,315 , 0,320, 82,0 and 4,0, and for the red colour: $0,570,0,305,16,0$ and 8,0 $0^{12}$. It is worth mentioning that since 1980, the issue of discoloration of the red colour has not been subject to any discussion. It may be hoped that the dispute over colours of the state flag has been definitely resolved.

\section{ALTERATIONS OF THE POLISH FLAG AFTER 1989}

The revision of the Constitution of the People's Republic of Poland that took place on December 29th, $1989^{13}$, did not affect the regulations on the state colours and the Polish flag. It was limited to modification of the state's name. The Act introduced numerous temporary periods for using the national symbols, including flags consistent with the old pattern. The longest temporary period applied to military symbols, which were to be altered by December 31st, $1997^{14}$.

11 JoL 1980 No. 7, item 18.

12 Ibidem, Attachment No. 2.

13 Ustawa z 29 grudnia 1989 r. o zmianie Konstytucji Polskiej Rzeczypospolitej Ludowej, JoL 1989 No. 75, item 444.

14 Ibidem, art. 4 par. 3. 
Detailed regulations concerning the colours and the flag of Poland were included in the Emblem, Colours and Anthem of the Republic of Poland Act ${ }^{15}$. As with the Constitution, no new legal act was adopted but slight amendments were introduced to the legal acts which were in force. The structural transformation that took place in 1989 did not lead to changes of the colours or the pattern of the state flag. Modifications were introduced to the flag with the coat of arms, as the new pattern included the coat of arms consistent with the pattern of 1999 (attachment no. 3 to the Act). Similar alterations affected the military flags and other special flags (Znamierowski, 2003).

The modifications to the binding legal regulations unfortunately left in force those norms which referred to the colours of white and red, the white and red flag and the white and red flag with the coat of arms as the state colours and flags. Thus, the terms 'national colours' and 'national flag' were not restored. At the same time, the usage of the white and red flag with the coat of arms was strictly regimented so that the right to use it was not even granted to the President of the Republic of Poland. It was an unusual situation as in most states there is either only one flag used by the citizens, offices and institutions or a national flag for the citizens and institutions and a flag with a coat of arms for state offices (Znamierowski, 2003).

The flag issue was regulated in the new Constitution of the Republic of Poland of April 2nd, 1997. Article 2 of the Constitution stipulated that "The colours of the Republic of Poland are white and red"16. The regulations of the new Constitution are the same as the regulations of 1989. Details concerning the colours are left to the statutes ${ }^{17}$.

The Emblem, Colours and Anthem of the Republic of Poland and State Seals Act of January 31st, 1980, is still in force. It has been amended many times. Between 1990 and 2009, 8 amendments to the Act were introduced, modifying the list of the subjects entitled to use the state symbols and the conditions of their usage. One of the modifications, which can be recognized as an attempt to restore the national colours to the citizens, was introduced in 2004. The conditions of the flag's usage were modified at that time. Article 5 was supplemented with an additional paragraph which stipulated that "Everyone has the right to use the colours of the Republic of Poland, especially in order to emphasize ceremonies, holidays

15 Art. 43 par. 1 Ustawy o godle, barwach i hymnie Polskiej Rzeczypospolitej Ludowej z 31 stycznia 1980 r., JoL 1980 No. 7, item 18.

16 Konstytucja Rzeczypospolitej Polskiej z 2 kwietnia 1997 r., JoL 1997 No. 78, item 483.

17 Ibidem, art. 28 par. 5. 
and other events [...]"18. Moreover, Article 6a, which established the Polish Flag Day (May 2nd), was added.

The above alterations were well received by the citizens, though there is a long way to go before the use of the white and red flag during national holidays becomes common. The introduced modifications had long been demanded by Polish constitutional law doctrine. One of the doctrine's representatives, P. Sarnecki, wrote: "The fact that the Constitution regulates the state symbols cannot lead to a conclusion that the usage of the symbols is limited only to public subjects or even to the organs of the Polish authorities. Quite the opposite - the usage of the symbols is available to all the citizens who created the Republic of Poland in its constitutional shape and whose common good is the Republic of Poland. One can even consider if there is a sort of a constitutional citizen right” (Sarnecki, 2007).

The anthem of the Republic of Poland is a completely different issue. Numerous songs were acknowledged as anthems throughout Polish history. The oldest song, “Gaude, mater Polonia" ("Rejoice, Mother Poland"), which dates back to the 13th century, was the anthem of the Piast dynasty (Panek, 1996). It was written in 1231 by a Polish Dominican, poet and composer, Wincenty z Kielczy (de Kielcza). Nowadays, this song is performed on special occasions, and almost always accompanies academic ceremonies.

The first knight's anthem in Poland was "Bogurodzica” ("Mother of God”), written in 1407. It is the oldest written and performed song in Polish acknowledged as an anthem in Poland. In the 15th century, the song was used as knight's reveille, chanted on battlefields. According to historical records, "Bogurodzica” was chanted by the Polish royal knights before the battle of Grunwald in 1410 (Panek, 1996).

Most of the anthemic songs, including the current anthem of Poland "Mazurek Dąbrowskiego” (“Dąbrowski’s Mazurka”), originated in the years 1795-1918, i.e., when Poland did not exist. The mazurka is also known as "The Song of the Polish Legions in Italy", and by its opening line "Poland Is Not Yet Lost” or "Poland Has Not Yet Perished”.

18 Ustawa z 20 lutego 2004 r. o zmianie ustawy o godle, barwach i hymnie Rzeczypospolitej Polskiej, JoL 2004 No. 49, item 467. 


\section{ORIGIN OF THE "DAQBROWSKI'S MAZURKA"}

The song originated in 1797. It was written by playwright, composer, lawyer and diplomat Józef Wybicki, in Italy, where he helped to organize the Polish Legions within the French Revolutionary Army. The Mazurka's melody is probably a modified version of a song popular in the 18th century in Pomerania. The song, which was created to add splendour to the departure of the Polish Legions, soon became popular among Poles. The vast popularity of "Dąbrowski’s Mazurka” caused it to be recognized as an unofficial Polish national anthem at the time the French protectorate established on Polish territory the Duchy of Warsaw (1807-1815) (Panek, 1996).

"Dąbrowski's Mazurka" was one of the most popular liberation songs in the 19th century in Europe. The song strongly affected other Slavic nations and became a prototype of many anthems. "Hej, Slované...”, a Czech song written in 1834 by Samuel Tomašik followed the Polish anthem's melody ${ }^{19}$. It was acknowledged as a universal Slavic anthem in 1848 by the Prague Congress. "Dąbrowski's Mazurka" was also the prototype of the Lusatian Serbs' anthem ${ }^{20}$, the Croatian anthem ${ }^{21}$, and the Ukrainian anthem²2. "Dąbrowski's Mazurka” also influenced the Bulgarian anthem of 1876 (Panek, 1996).

\section{THE ANTHEM IN THE SECOND REPUBLIC OF POLAND}

Despite its vast popularity, "Dąbrowski's Mazurka” was not acknowledged as the Polish anthem. When Poland re-emerged as an independent nation after the First World War in 1918, the second song competing for the status of an official national anthem was “Boże, coś Polskę” (“God Save Poland”) (Rosner, 2003). The conservatives preferred this song due to the fact that it was a church song which imitated the British anthem "God Save the King”. "Boże, coś Polskę” was known among other Slavic nations, but not as well as "Dąbrowski's Mazurka”. It was also translated into Hungarian, German, and Italian (Panek, 1996).

19 The post-war anthem of Yugoslavia was a song written by Tomašik to the slightly slower melody of the "Mazurek Dąbrowskiego".

20 „Hisce Serbstvo njeshubjene”.

21 „Jaś Horvatska nij propala”.

22 „Szcze ne umerła Ukraina”. 
During the first years of independence the question of the national anthem was left unanswered. The Constitution adopted in 1921 did not regulate the issue of national symbols. However, after it had been passed, the song "Boże, coś Polskę" was chanted (Kijowski, 2004). On the other hand, official Polish delegations were welcomed at that time with the sounds of songs such as: "Rota", "Warszawianka", "Mazurek Dąbrowskiego”, or "Boże, coś Polskę” (Panek, 1996). It was an unprecedented situation.

The acknowledgement of "Dąbrowski's Mazurka" as the national anthem was made through numerous legal acts. The Minister of Military Affairs, by an order of March 22nd, 1921, commanded that military honours be awarded accompanied by a performance of the Mazurka and the anthems of the Allies, levelling them in terms of military ceremonial (Kijowski, 2004). "Dąbrowski’s Mazurka” was first described as the national anthem in the order of the Minister of the Military Affairs of November 2nd, 1921, which regulated the issue of the national anthem's performance during military ceremonies. The Ministry of Religious Beliefs and Public Enlightenment issued a circular of February 26th, 1927 on the national anthem pertaining to school occasions, which declared the Mazurka as the only anthem of Poland. February 26th, 1927 is considered to be the official date of the acknowledgment of "Dąbrowski's Mazurka” as the anthem of the Republic of Poland (Kijowski, 2004). It may seem surprising that the issue of the national anthem was left to legal acts at such low levels in the hierarchy, especially due to the fact that the stylization of the coat of arms or the colours of the flag were highly regarded at the same time. It is said that the issue of the anthem was treated as an element of customary law (Górecki, 2008). This thesis is confirmed by the fact that the anthem was not regulated in legal acts of higher rank until 1939 (Kijowski, 2004).

\section{THE ANTHEM IN THE PEOPLE'S REPUBLIC OF POLAND}

From the beginning of the People's Republic of Poland, the state used the national symbols introduced in the Second Republic of Poland. However, the symbols were either gradually modified or replaced. In 1946, the leading state and party activists appealed for a new national anthem which would reflect the spirit of the new age. The appeal was badly received in artistic circles. In the end, "Daąbrowski's Mazurka" remained the Polish state anthem because of Joseph Stalin, who did not support the then President's (Bolesław Bierut) attempts to create a new anthem (Kijowski, 2004). 
The indecisive Polish parliament did not adopt any decision regarding the anthem, which led to a situation similar to that of the 1920s. The issue of the anthem was regulated for the first time after 1945 in a legal act of low rank. On April 20th, 1948, the Ministry of Education introduced "Dąbrowski’s Mazurka" as the anthem for use by the 'studying youth' (Panek, 1996). The Constitution of the People's Republic of Poland of July 22nd, 1952 did not regulate the issue of the anthem, which was not surprising as its prototype - the Constitution of the Soviet Union of 1936 - also ignored the issue. Many proponents of constitutional law doctrine agreed on the uselessness of such regulations, arguing that the issue of a national anthem was an element of customary law (Kijowski, 2004).

The increase of the rank of the legal act regulating the issue of a national anthem occurred in the 1970s due to the State Council's resolution on the conditions of the national celebrations and the local state ceremonies of March 8th, 1973. The state anthem was regulated in the Constitution of 1976. It was a result of a thorough amendment of the Constitution of the People's Republic of Poland of July 22nd, $1952^{23}$. It may be considered paradoxical that the most controversial amendment in the history of the People's Republic of Poland (introducing - among other numerous regulations - the phrases about the communist party having a leading role, and about friendship and cooperation with the Soviet Union) simultaneously raised to constitutional rank the legal regulations regarding a national anthem. Article 89 was supplemented with paragraph 3 which acknowledged "Dq̨browski’s Mazurka” as the anthem of Poland ${ }^{24}$, which made it subjected to a special protection. In 1976, directly after the constitutional amendment, a consolidated text was announced. It changed the numeration of several articles and moved the regulations of the anthem to Article $103(3)^{25}$.

Detailed regulations on the national and state symbols were included in the Act on the Emblem, Colours and Anthem of the People's Republic of Poland of January 31st, $1980^{26}$. This act cleared up the regulated issues. It should also be appreciated that the rank of legal regulations regarding state symbols was raised to a statutory level. Article 12 of the Act repeated after the Constitution that "Dąbrowski's Mazurka” is the state anthem, settled the anthem's lyrics (attachment no. 4) and melody

23 Ustawa z 10 lutego 1976 r. o zmianie Konstytucji Polskiej Rzeczypospolitej Ludowej, JoL 1976 No. 5, item 29.

24 Ibidem, art. 1 par. 46.

25 Obwieszczenie Przewodniczącego Rady Państwa z dnia 16 lutego 1976 r. w sprawie ogłoszenia jednolitego tekstu Konstytucji Polskiej Rzeczypospolitej Ludowej uchwalonej przez Sejm Ustawodawczy 22 lipca 1952 r., JoL 1976 No. 7, item 36.

26 JoL 1980 No. 7, item 18. 
(attachment no. 5) and entrusted the supervision over the musical interpretation to the Minister of Culture; Article 13 of the Act determined the circumstances under which the anthem was to be performed and Article 14 introduced exact rules of behaviour during the performance of the anthem.

\section{THE ANTHEM IN THE REPUBLIC OF POLAND, 1989}

The constitutional revision of December 30th, 1989, as well as the amendments introduced to the Act on the Emblem, Colours and Anthem of 1980, did not affect the state anthem. The Act of 1980 was subjected to numerous amendments after 1989. However, all the modifications introduced did not bring significant changes in terms of the state anthem. The Constitution of the Republic of Poland of 1997, which regulates the anthem and other state symbols in Article 28, confirmed the legal stabilization of the issue ${ }^{27}$. Article $28(3)$ is concurrent with previous constitutional regulations.

\section{References:}

Borucki, M. (2006). Polskie symbole narodowe. Warszawa: Mada.

Górecki, D. (2008). Symbole i stolica państwa. In: D. Górecki (ed.), Polskie prawo konstytucyjne (pp. 52-55). Warszawa: Wolters Kluwer.

Kijowski, M. (2004). Polski hymn państwowy jako zagadnienie konstytucyjnoprawne. Ius et Administratio, 3, 121-140.

Panek, W. (1996). Hymny polskie. Poznań: Grupa Wydawnicza „Słowo”.

Rosner, A. (2003). Prawnoustrojowe symbole Rzeczypospolitej szlacheckiej na ziemiach polskich w początkach XIX wieku. Studia Iuridica, 42, 191-203.

Russocki, S., Kuczyński, S., Willaume, J. (1978). Godło, barwy i hymn Rzeczypospolitej. Warszawa: Wiedza Powszechna.

Sarnecki, P. (2007). Artykuł 28. In: L. Garlicki (ed.), Konstytucja Rzeczypospolitej Polskiej. Komentarz (pp. 1-4), Vol. V. Warszawa: Wydawnictwo Sejmowe.

Znamierowski, A. (2003). Insygnia, symbole i herby polskie. Kompendium. Warszawa: Świat Książki. 